Cardiac Morphogenesis and Teratogenesis. Raven Press, New York, pp 389399

20. Van Praagh S, Truman T, Firpo A, Bano-Rodrigo A, Fried R, Mcmanus B, Engle MA, Van Praagh R 1989 Cardiac malformation in trisomy-18: a study of 41 postmortem cases. J Am Coll Cardiol 13:1586-1597

21. Matsuoka R, Misugi K, Goto A, Gilbert EF, Ando M 1983 Congenital heart anomalies in the trisomy 18 syndrome, with reference to congenital polyvalvular disease. Am J Med Genet 14:657-668

22. Emerit I, De Grouchy J, Vernant P, Corone P 1967 Chromosomal abnormalities and congenital heart disease. Circulation 36:886-929

23. Nora JJ, Nora AH 1984 The environmental contribution to congenital heart diseases. In: Nora JJ, Takao A (eds) Congenital Heart Disease. Causes and Processes. Futura Publishing Co, New York, pp 15-27

24. Nora JJ 1968 Multifactorial inheritance hypothesis for the etiology of congenital heart diseases. The genetic-environmental interaction. Circulation 38:604-617

25. Fraser FC 1976 The multifactorial/threshold concept-uses and misuses. Teratology 14:267-280
26. Sasaki M, Kodama Y, Hayata I, Yoshida MC 1979 Chromosome markers in 12 inbred strains of the norway rats. Rattus norvegicus. Cytogenet Cell Genet 23:231-240

27. Goodenough U 1987 Related genes: alleles, isoloci, and gene families. In: Genetics, 3rd Ed. Everbest Printing Co, Ltd, Hong Kong, pp 591-617

28. Gruenberg H 1951 The genetics of tooth defect in the mouse. Proc R Soc Lond [Biol] 138:437-451

29. Gruenberg H 1952 Genetical studies in the skeleton of the mouse. IV. Quasicontinuous variations. J Genet 51:95-114

30. Haverkamp Begemann N, Van Lookeren Campagne A 1952 Homozygous form of Pelger-Huet's nuclear anomaly in man. Acta Haematol (Basel) 7:295-303

31. Goodenough U 1987 Genes that cooperate to produce complex phenotypes and quantitative traits. In: Genetics, 3rd Ed. Everbest Printing Co Ltd, Hong Kong, pp 642-680

32. Lalouel JM 1987 Common disease: from phenotype to genotype. In: Vogel F Sperling K (eds) Human Genetics. Proceedings of the 7 th International Congress Berlin 1986. Springer-Verlag, Berlin, pp 294-301

\title{
Announcement
}

\section{Society for Adolescent Medicine Annual Meeting}

The Society for Adolescent Medicine will hold its annual meeting from March 19 to March 22, 1992 in Washington, DC at the Omni Shoreham Hotel. The theme for this meeting will be "Adolescent Health Policy and Advocacy." In addition to addressing this topic, the Society will present new material on a broad range of issues important to adolescent physical and emotional health, including AIDS, teenage sexuality and pregnancy, eating disorders, depression, and risk-taking behaviors such as drug and alcohol use. Meeting presentations include all-day workshops, 3-hour clinically oriented workshops, research networking breakfasts and luncheon seminars, scientific research paper presentations, and poster sessions, as well as the prestigious Gallagher Lecture Series. CME/CEUs are available. For additional information, contact: the Society for Adolescent Medicine, Suite 120, 19401 E. U.S. Highway 40, Independence, MO 64055 or call (816) 795-8336. 